\title{
BRONCHIAL INVOLVEMENT IN PULMONARY SARCOIDOSIS $\frac{\overline{\frac{\sigma}{\bar{m}}}}{\overrightarrow{\frac{\pi}{2}}}$
}

\author{
BY \\ VATCHE V. KALBIAN \\ Fro:n Milford Chest Hospital, Godalming, Surrey
}

(RECEIVED FOR PUBLICATION SEPTEMBER 7, 1956)

It is probable that the lung is one of the commonest sites of involvement by sarcoidosis. In spite of the rapidly growing literature on the subject there is scanty mention of the disease affecting bronchi. This can be attributed to the fact that routine bronchoscopic and bronchial biopsy investigations have not been carried out in pulmonary sarcoidosis.

In the study described in this paper an attempt was made to find out the frequency of bronchial disease in pulmonary sarcoidosis and to assess the value of bronchoscopic biopsy as a diagnostic procedure. The cases investigated complied with the definition of the U.S. National Research Council as quoted by Ricker and Clark (1949). All had histological evidence of epithelioid cell tubercles without central caseation (non-caseating tubercles) and with or without Langhans type giant cells. At the same time no tubercle bacilli could be grown from cultures of the sputum or cultures of lymph node tissue and no tubercle bacilli were seen on histology.

\section{MATERIAL}

The last 11 consecutive cases at this hospital considered on clinical and radiological grounds to be suffering from pulmonary sarcoidosis in a period of nearly a year were examined bronchoscopically under general anaesthesia ; at the same time a bronchial biopsy was taken. In addition a scalene or other lymph node was removed for biopsy. The bronchial biopsy was taken either from a region where the mucous membrane looked abnormal, or, if the mucous membrane was normal, from the bronchus supplying the most diseased area of lung. Biopsy material was examined for tubercle bacilli by Ziehl-Neelsen's method, and histologically after staining with haematoxylin and eosin and by the silver method.

Table I gives the relevant particulars of the patients. There were five women and six men with ages varying from 22 years to 45 years. All had radiological evidence of lesions in the lungs and a

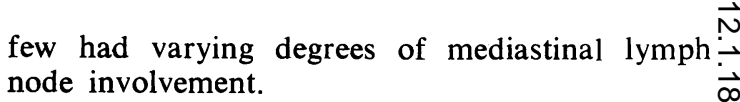

The duration of the disease, as far as could be을 deduced from the history, varied from six months to at least five years in one case (No. 7). All except 3 Case 1 had symptoms. Case 1 had been found at $\frac{2}{3}$ mass radiography two years before admission to $\mathcal{S}$ hospital to have massive enlargement of medi- $\overrightarrow{0}$ astinal lymph nodes without other change. Gradu- . ally these nodes became smaller, and, three months $\square$ before admission to hospital, miliary mottling of both lung fields appeared.

Case 6 presented with erythema nodosum, Case 3 with a pleural effusion, and Case 9 with haem- $\frac{}{\mathbb{D}}$ optysis. The remainder had cough and expectora- $\stackrel{\varrho}{\longrightarrow}$ tion, with or without dyspnoea on exertion, as theiro을 presenting symptoms.

\section{Findings}

BRONCHOSCOPY.-Four of the 11 cases studied had no specific bronchoscopic abnormality, except slight increase of mucous secretion in two and a 3 . tendency to bleed easily from the mucous mem- $\delta$ brane in one. Two (Cases 4 and 6) showed distor- 3 tion of the carina presumably due to enlargedo mediastinal lymph nodes which were evident? radiographically. In four cases, including Case 6 , 을 which also showed distortion of the carina, the mucosa was granular and rough-looking and bled $\mathcal{N}$ easily. The granularity was due to small bleb- N like elevations 2 to $3 \mathrm{~mm}$. in diameter. Finally స్ల two cases had a very thickened mucous membrane ${ }_{\sigma}^{\omega}$ with narrowing of the bronchus and oedema. In Case 9, the mucosa looked acutely inflamed. The chest radiograph of this case (Fig. 1) showed the disease mainly in the middle and lower zones of the right lung. The bronchogram (Fig. 2) con-o firmed the bronchoscopic finding of stenosis of the whole right bronchial tree, the middle and lower $\frac{?}{\mathbb{1}}$ lobe bronchi being most severely involved. The 을 right scalene node removed for biopsy showed? non-caseating tubercles (Fig. 3). 


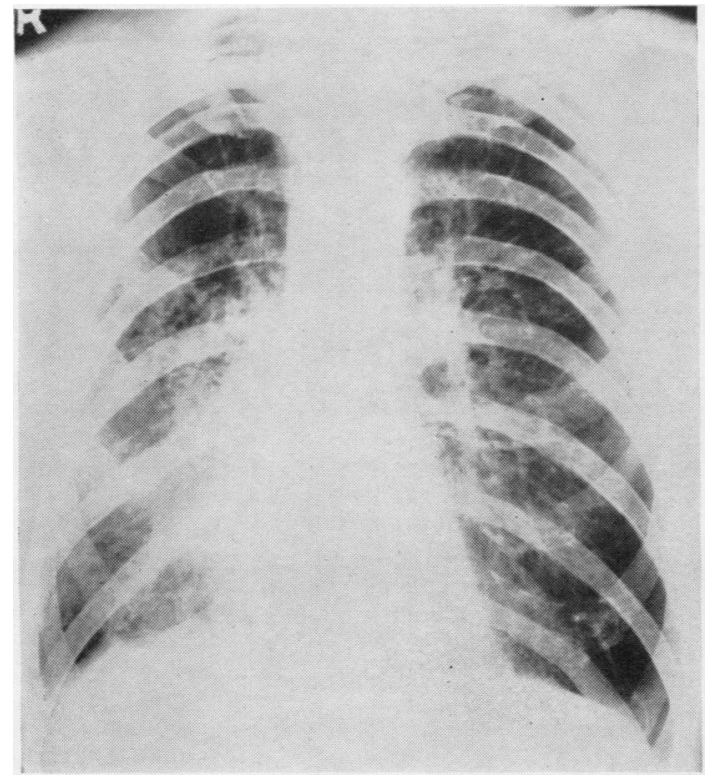

Fig. 1

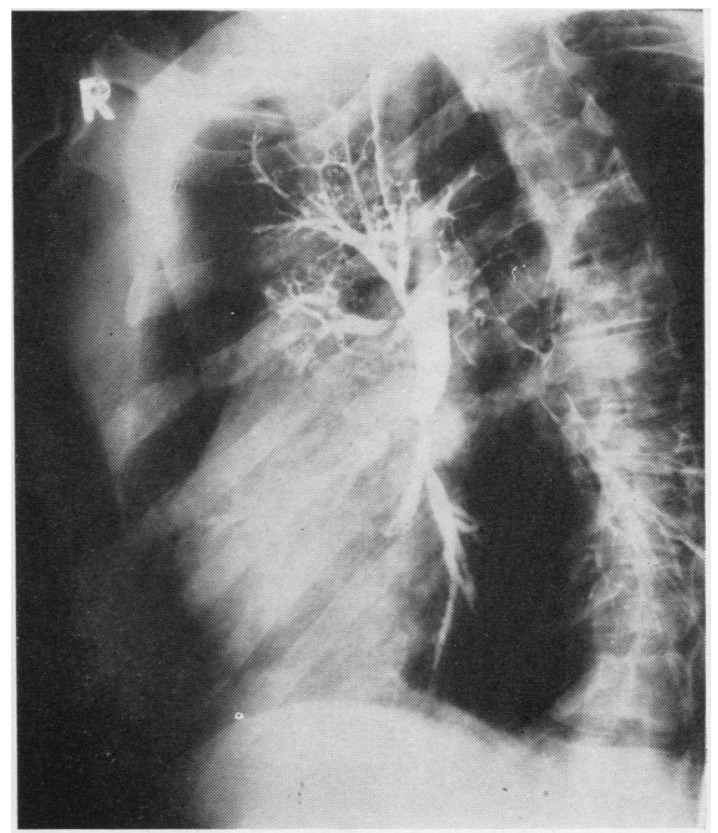

FIG. 2
FIG. 1.-Chest radiograph of Case 9.

FIG. 2.-Left oblique view of right bronchogram in Case 9.

FIG. 3.-Scalene node (Case 9), showing noncaseating tubercles in lymphatic tissue. Haematoxylin and eosin, $\times 107$.

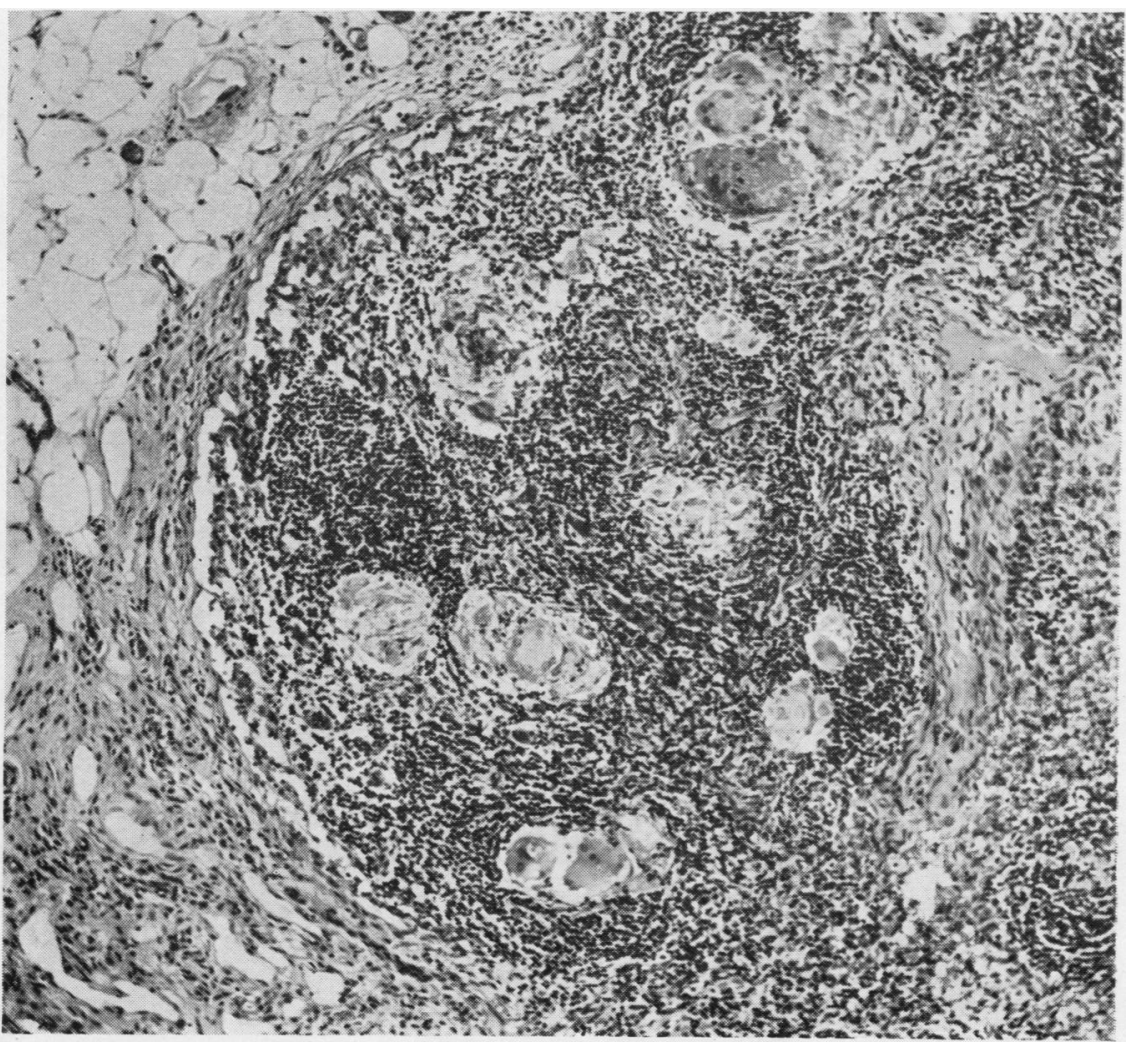

FIG. 3 
TABLE I

SUMMARY OF FINDINGS IN 11 CASES OF SARCOIDOSIS EXAMINED BRONCHOSCOPICALLY

\begin{tabular}{|c|c|c|c|c|c|c|c|c|c|c|}
\hline \multirow{3}{*}{ Case } & \multirow{3}{*}{ Sex } & \multirow{3}{*}{$\begin{array}{l}\text { Age } \\
\text { (yr.) }\end{array}$} & \multirow{3}{*}{$\begin{array}{l}\text { Estimated } \\
\text { Duration } \\
\text { of } \\
\text { Disease }\end{array}$} & \multicolumn{2}{|c|}{ Chest Radiograph } & \multirow{2}{*}{\multicolumn{2}{|c|}{$\underset{\text { Biopsy }}{\text { Lymph Node }}$}} & \multirow{3}{*}{ Bronchoscopy } & \multirow{3}{*}{ Bronchial Biopsy } & \multirow{3}{*}{$\begin{array}{l}\text { Presenting } \\
\text { Symptoms }\end{array}$} \\
\hline & & & & \multirow{2}{*}{$\begin{array}{l}\text { Hilar } \\
\text { Lymph } \\
\text { Nodes }\end{array}$} & \multirow{2}{*}{ Lungs } & & & & & \\
\hline & & & & & & Site & Result & & & \\
\hline 1 & $\mathbf{M}$ & 27 & 2 years & + & Miliary shadows & Scalene & N.C.T. & Excess mucus & $\begin{array}{l}\text { Fibrous thickening of } \\
\text { submucosa with } \\
\text { scanty lymphocytic } \\
\text { infiltraion }\end{array}$ & None \\
\hline 2 & $\mathbf{F}$ & 33 & 6 months & - & Fine mottling & , & $\begin{array}{l}\text { Giant } \\
\text { cells }\end{array}$ & Mucosa bled easily & $\begin{array}{l}\text { Submucosal thicken- } \\
\text { ing }\end{array}$ & $\begin{array}{l}\text { Dyspnoea. } \\
\text { lassitude }\end{array}$ \\
\hline 3 & $\mathbf{M}$ & 34 & 2 years & $\overrightarrow{+}$ & "̈ry slight fine & A’’llary & N.C.T. & Excess mucus & No biopsy & Pleurisy \\
\hline & & 34 & 6 months & $7+t$ & mottling & Axilary & ", & Carma distorted & $\begin{array}{l}\text { with fibrosis of } \\
\text { submucosa }\end{array}$ & Dyspinued \\
\hline 5 & $\mathbf{F}$ & 39 & 2 years & + & $\begin{array}{l}\text { Coarse mottling } \\
\text { and fibrosis }\end{array}$ & Scalene & , & $\begin{array}{c}\text { Structurally normal } \\
\text { mucosa, granular } \\
\text { and alittle red allove }\end{array}$ & Normal & $\begin{array}{l}\text { Lassitude, } \\
\text { dyspnoea }\end{array}$ \\
\hline 6 & $\mathbf{F}$ & 22 & 9 months & $t+$ & Fine mottling & [Liver] & ", & $\begin{array}{l}\text { Carina distorted, excess } \\
\text { mucus, granular, } \\
\text { rough mucosa }\end{array}$ & N.C.T. & $\begin{array}{l}\text { Erythema nod } \\
\text { osum, n } \\
\text { chest symp }\end{array}$ \\
\hline 7 & $\mathrm{~F}$ & 38 & 5 years & + & $\begin{array}{l}\text { Fine mottling } \\
\text { and linear fib- } \\
\text { rosis }\end{array}$ & Scalene & ", & $\begin{array}{l}\text { Excess mucus, mucosa } \\
\text { rough and a little } \\
\text { oedematous }\end{array}$ & , & $\begin{array}{l}\text { Cough, } \\
\text { sputum }\end{array}$ \\
\hline 8 & $\mathbf{F}$ & 39 & 6 months & + & Fine mottling & , & Normal & $\begin{array}{l}\text { Mucosa thickened, up- } \\
\text { per and lower lobe } \\
\text { orifices narrowed }\end{array}$ & $\begin{array}{l}\text { Epithelioid cells and } \\
\text { giant cells }\end{array}$ & $\begin{array}{l}\text { Cough, spu- } \\
\text { tum, dyspnoe }\end{array}$ \\
\hline 9 & $\mathbf{M}$ & 42 & 1 year & - & $\begin{array}{l}\text { Fine mottling in } \\
R \text {. lung, most } \\
\text { in lower } 23 \\
\text { with linear } \\
\text { fibrosis }\end{array}$ & ," & N.C.T. & $\begin{array}{l}\text { Mucosa of whole R. } \\
\text { bronchus inflamed } \\
\text { and oedematous, } \\
\text { with stenosis mainly } \\
\text { of middle and lower } \\
\text { lobe bronchi }\end{array}$ & $\begin{array}{l}\text { Giant cells of Lang- } \\
\text { hans type }\end{array}$ & $\begin{array}{l}\text { Haemoptysis, } \\
\text { wheezing, } \\
\text { cough, } \\
\text { sputum }\end{array}$ \\
\hline 10 & $\mathbf{M}$ & 34 & 6 months & - & Fine mottling & , & , & Normal & Submucosa thickenec & $\begin{array}{l}\text { Lassitude, } \\
\text { cough, sputun }\end{array}$ \\
\hline 11 & $\mathbf{M}$ & 45 & 2 years & + &, & , & , & $\begin{array}{l}\text { Mucosa of right upper } \\
\text { lobe bronchus slight- } \\
\text { ly irregular and hy- } \\
\text { peraemic }\end{array}$ & N.C.T. & Dyspnoea \\
\hline
\end{tabular}

The bronchoscopic findings could be summarized in four groups: (1) No abnormality detectable (four cases); (2) external lymph node pressure causing deformity (two cases); (3) granular and rough mucous membrane (four cases); (4) oedematous, thickened and inflamed mucous membrane with possible stenosis of bronchus (two cases). One case showed changes of both group (2) and group (3).

BRONCHIAL BIOPSY.-In 10 of the 11 cases, specimens of bronchial mucosa were taken for biopsy. In one, the mucous membrane was histologically normal. In three, there was fibrous thickening of the submucosa. In three, in addition to thickening of the submucosa, there were giant cells of the Langhans type. Finally, three cases showed definite tubercles without central caseation. Fig. 4 is the chest radiograph of Case 6 and Fig. 5 shows the bronchial biopsy of the same case with several non-caseating tubercles in the submucosa.

Summarizing in table form the biopsy findings:

(a) Normal mucous membrane $\quad \ldots \quad \ldots \quad \ldots \quad \ldots \quad$ case (b) Thickening of mucous membrane $\quad \ldots \quad \ldots \quad \ldots \quad 3$ cases (c) Thickening of mucous membrane + giant cells $\quad \ldots .3$ cases
The non-caseating tubercles were found in the three cases that showed roughness and granularity言 of the mucous membrane. On the other hand two of the cases with bronchostenosis and oedema of

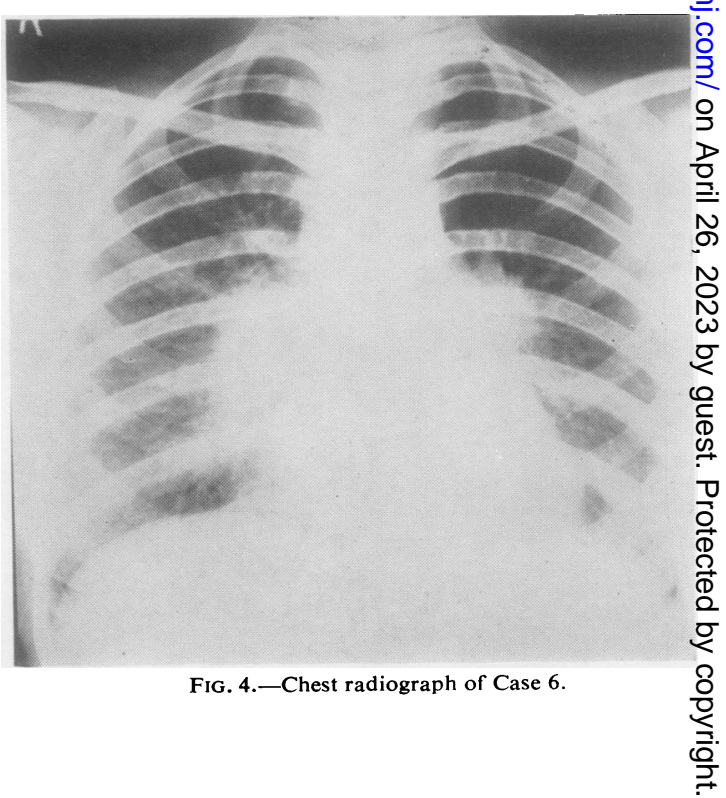


tous and inflamed mucous membrane showed only fibrosis with giant cells of the Langhans type. Could they have been a more advanced stage in the natural history of the sarcoid granuloma?

If an attempt is made to correlate the bronchoscopic with the bronchial biopsy findings it seems that with a normal bronchoscopic appearance no more than some thickening of the mucous membrane can be expected, while with a granular rough mucous membrane non-caseating tubercles may be found, the granular surface of the mucous membrane being due to collections of non-caseating tubercles in the submucosa.

Scalene Node Biopsy.-Of the 11 cases, one (Case 6) had had a liver biopsy before admission ; this had shown non-caseating tubercles so no lymph node biopsy was performed. One case (Case 4) had enlarged axillary lymph nodes, one of which was removed for biopsy and showed non-caseating tubercles.

Of the remaining nine none had enlarged palpable lymph nodes, and in all the scalene node was re-

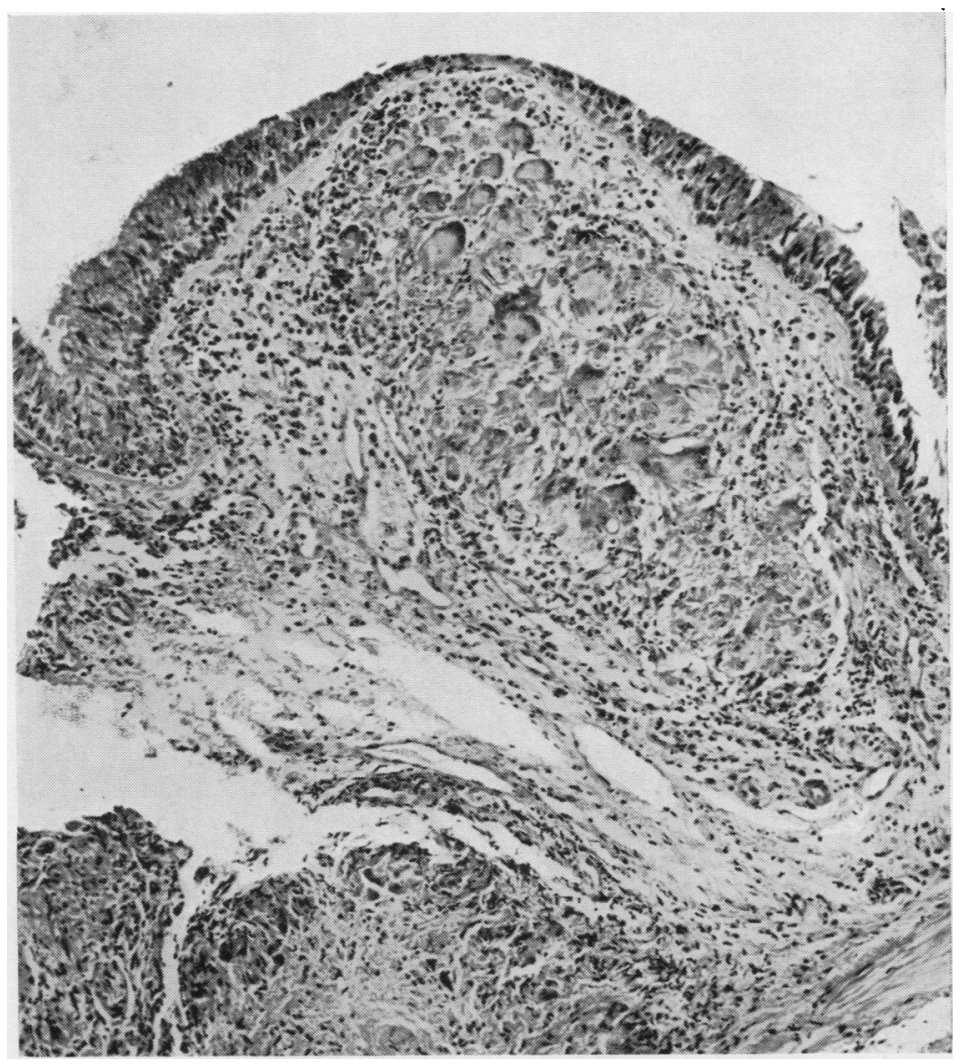

FIG. 5.-Bronchial biopsy of Case 6, showing non-caseating tubercles in the submucosa. Haematoxylin and eosin, $\times 107$. moved. One of these was normal,
one showed groups of giant cells of the Langhans type, and the remaining seven $(77 \%)$ had noncaseating tubercles.

\section{REVIEW OF THE Literature}

It has only been possible to trace 11 individual case reports of bronchial wall involvement by sarcoidosis confirmed by bronchoscopic biopsy in the medical literature. Benedict and Castleman (1941) described the first case. It was a 20-yearold woman who had radiographic evidence of large mediastinal lymph nodes but no pulmonary lesions. Bronchoscopy showed numerous bleblike nodules 2 to $3 \mathrm{~mm}$. in diameter in the main bronchi, whose lumina were narrowed. Bronchial biopsy showed non-caseating epithelioid cell tubercles with giant cells. Olsen (1946) reported the case of a 47-year-old man who had radiographic evidence of enlarged bilateral hilar lymph nodes with infiltration in the upper zone of the right lung. Bronchoscopy showed a faintly nodular appearance of the lateral wall of the right main bronchus, and biopsy confirmed the presence of epithelioid cell tuberculoid granulomata surrounded by lymphocytes. There was no caseation. Jacobs (1949) reported a case with generalized sarcoidosis, the chest radiograph showing miliary nodules and enlarged hilar lymph nodes on both sides. Bronchoscopy showed narrowing of the left main bronchus by external pressure and several faintly haemorrhagic flat areas 2 to $3 \mathrm{~mm}$. in diameter in the right main bronchus. On histology, these areas showed non-caseating tubercles with many giant cells in the submucosa. Harvier, Turiaf, Claisse, and Rose (1950) and Turiaf, Marland, Rose, and Sors (1952) reported five cases of pulmonary sarcoidosis with bronchial lesions confirmed by bronchoscopy and bronchial biopsy. They claim that in all their five cases the bronchial tree was the site of changes more or less apparent, but always sufficient to attract attention. Sometimes they were generalized over the whole tracheo-bronchial tree and at times localized to a bronchus or to a lobe. The findings at broncho- 
scopy varied from thickening of the mucous membrane to inflammatory changes. They found bronchial biopsy a very valuable investigation. In all their cases they found the typical histology of sarcoidosis whether the chest radiograph showed slight or severe lung involvement. The sarcoid tubercles were seen below the bronchial mucous membrane and the epithelium was usually intact, although occasionally it was eroded.

Siltzbach and Som (1952) reported two more cases. One was a 40-year-old man who had evidence of hilar adenopathy and "shrinkage" and consolidation of the right middle lobe on a chest radiograph, together with fine linear and nodular densities scattered throughout both lung fields. Bronchoscopy showed the mucosa of the middle lobe bronchus to be granular and thickened and narrowed. Biopsy showed non-caseating epithelioid cell tuberculoid granulomata consistent with sarcoidosis. The second case was of a 35-year-old woman who had a chest radiograph showing enlargement of lymph nodes in both hilar areas with some linear densities in the medial and lower part of the right lung field. On bronchoscopy there was some narrowing of the right bronchus above the level of the middle lobe bronchial orifice. The left main bronchus was also narrowed but to a lesser extent. The narrowing in both instances was due to external pressure and the mucous membrane was normal. In the middle lobe bronchus, however, the mucosa was thickened, leading to virtual occlusion of this bronchus. Biopsy showed many non-caseating epithelioid tuberculoid granulomata containing many giant cells of the Langhans type. Finally, Cowdell (1954), discussing the diagnosis of 90 cases of sarcoidosis, mentioned that in one case the diagnosis was confirmed by histological findings at bronchial biopsy.

\section{Discussion}

Combining the experience of 11 cases with the 11 cases from the literature, it seems that there are three possible abnormal bronchoscopic findings in pulmonary sarcoidosis: (1) External pressure (from enlarged lymph nodes); (2) granular, nodular, rough-looking mucous membrane with small blebs 2 to $3 \mathrm{~mm}$. in diameter; (3) thickened, oedematous mucous membrane with stenosis of the bronchus.

Of the bronchoscopic changes described above, Group 1 is not specific to sarcoidosis, as lymph node enlargement may be due to many other causes. Group 3 is not specific either, as it is the end-result of a fibrosing process with secondary changes brought on by superimposed infection. $\stackrel{\vec{F}}{\vec{P}}$ Group 2 is very probably a typical change of pul-? monary sarcoidosis with bronchial wall involvement. When the mucosa showed this granular $\frac{\bar{\sigma}}{\bar{D}}$ appearance, both in the cases described in the $\stackrel{\overparen{Q}}{\stackrel{Q}{ }}$ literature and in the cases in this series, non-» caseating tubercles were found on histology of $\vec{\circ}$ bronchial biopsy.

There is no doubt that bronchoscopy can show $\overrightarrow{\vec{\omega}}$ abnormalities in pulmonary sarcoidosis. Is it an examination worth doing ? Its diagnostic value $\vec{x}$ depends mainly upon the incidence of bronchial $\vec{N}$ involvement. The series reported here is too small as statistical evidence, but considering that the $\vec{\infty}$ cases have been unselected and of varying degrees 0 of severity and duration, it is significant that seven out of 11 showed bronchoscopic abnormality and $\vec{z}$ that nine out of 10 bronchial biopsies were abnormal. Bronchial disease has not been a widelyş recognized feature of pulmonary sarcoidosis. $\vec{\varphi}$ Before a final opinion on its incidence is given o more routine bronchoscopic and biopsy examina-: tions must be done. There are certain difficultieso and objections to bronchial biopsy as a diagnostic aid. One is that biopsy material is usually small. The other is the difficulty of choosing a site for the biopsy if the mucous membrane appears nor- $\varrho$ mal. It is reasonable to take it from the bronchus $\vec{O}$ which drains the area which, on the radiograph, 3 shows the maximum disease.

As to scalene node biopsy, it is sufficient to say? that seven out of nine cases gave histological

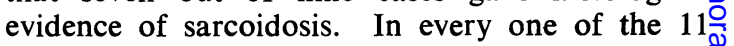
cases studied there was positive histological evidence of sarcoidosis in either the scalene node and in bronchial mucosa or in both these tissues.

The final diagnosis of sarcoidosis should be histological, with demonstration of the non-o caseating tubercles. Biopsy examination of distant? organs has been recommended. In pulmonary sarcoidosis it seems that histological evidence of the disease is more likely to be found in the lungs and its draining lymph nodes than in distantr organs. It is true that sarcoidosis is often on generalized disease, but it is not necessarily so. $\operatorname{In}^{\omega}$ all of the 11 cases reported in this paper, histo logical evidence was obtained from either a scalen node or from bronchial mucosa, and in some fromes both. In no case had we to resort to biopsy of other organs for diagnosis. I suggest that everyo case of pulmonary sarcoidosis should be inves $\overrightarrow{\mathrm{D}}$ tigated by bronchoscopy with bronchial biopsy and by scalene node biopsy if there are no palo pable lymph nodes. It is doubtful if after these procedures there will be many cases in which liver 8 
biopsy will be necessary to secure histological evidence. Turiaf and others (1952) wrote: "By its importance and its practical interest bronchoscopy should occupy a privileged place amongst the hierarchy of investigations considered indispensable for establishing the diagnosis of (pulmonary) sarcoidosis."

\section{SUMMARY}

Eleven consecutive cases of pulmonary sarcoidosis have been investigated by bronchoscopy, bronchial biopsy and scalene node biopsy. This investigation has suggested that the bronchi are frequently involved, that pulmonary sarcoidosis can usually be diagnosed by histology of bronchial biopsy material, and that a combination of bronchial biopsy and scalene node biopsy is the best way to obtain histological evidence of pulmonary sarcoidosis.

I wish to express my thanks to Dr. F. E. Joules for his encouragement and help, to Mr. M. Meredith Brown for bronchoscopies and biopsies, and to Dr. W. K. Taylor, group pathologist, for help in the histological studies.

\section{REFERENCES}

Benedict, E. B., and Castleman, B. (1941). New Engl. J. Med., 224, 186.

Cowdell, R. H. (1954). Quart. J. Med., 23, 29

Harvier, P., Turiaf, J., Claisse, R., and Rose, J. (1950). Bull. Soc. méd. Hôp., Paris, 66, 192.

Jacobs, E. (1949). Acta clin. belg., 4, 301.

Olsen, A. M. (1946). Ann. Otol. (St. Louis), 55, 629.

Ricker, W., and Clark, M. (1949). Amer. J. clin. Path., 19, 725.

Siltzbach, L. E., and Som, M. L. (1952). J. Mt Sinai Hosp., $19,473$.

Turiaf, J., Marland, P., Rose, Y., and Sors, C. (1952). Bull. Soc. méd. Hôp., Paris, 68, 1098. 